\title{
PENGISIAN PEMBULUH DARAH KAPILER PADA PASIEN DIABETIC FOOT ULCER
}

\section{(FILLING THE CAPILER BLOOD VESSEL IN PATIENT DIABETIC FOOT ULCER)}

\author{
Mashuri \\ Akademi Keperawatan Pemkab Lumajang \\ e-mail: mashuri0702@yahoo.com
}

\begin{abstract}
ABSTRAK
Diabetes Mellitus ( DM ) yang dikenal juga dengan kencing manis atau kencing gula menjadi penyakit yang divonis 'tidak bisa sembuh'. Dalam daftar rengking pembunuh manusia, DM menduduki peringkat keempat. Pada Kongres Federasi Diabetes Internasional di Paris tahun 2003 terungkap bahwa sekitar 194 juta orang di dunia mengidap penyakit ini. Badan Kesehatan Dunia (WHO) memperkirakan pada tahun 2025 jumlah penderitannya akan melonjak sampai 333 juta orang. Di Indonesia predikat diabetes mengenai lebih dari 2,5 juta orang dan diperkirakan terus bertambah, sehingga insiden DFU (luka kaki diabetikpun) bertambah seiring dengan bertambanya jumlah penderita diabet. Desain penelitian ini menggunakan desain deskriptif yang bertujuan untuk menguraikan tentang pengisian pembuluh darah kapiler pada pasien diabetic foot ulcer berdasarkan nilai ankle brachial index. Hampir keseluruhan pasien diabetic foor ulcer di ruang interna RSUD Dr. Haryoto Lumajang mengalami gangguan pengisian pembuluh darah kapiler, dari mulai yang ringan hingga yang berat. Dan hanya ada sebagian kecil responden saja yang tidak mengalami gangguan. Pengaturan pola makan dan latihan jasmani untuk mengendalikan kadar gula darah pasien DM sangat penting, mengingat gangguan pengisian pembuluh darah kapiler sering terjadi pada pasien DM

Kata kunci: pengisian pembuluh darah kapiler, diabetic foot ulcer
\end{abstract}

\section{ABSTRACT}

Diabetes Mellitus (DM) is also known as diabetes or sugar urine into a disease that was convicted 'can not recover'. In the list of human killer racking, DM ranked fourth. At the International Diabetes Federation Congress in Paris in 2003 it was revealed that about 194 million people worldwide suffer from the disease. The World Health Organization (WHO) estimates that by 2025 the number of diabet sufferers will jump to 333 million people. In Indonesia, diabetes predicates more than 2.5 million people and is expected to increase, so the incidence of DFU (diabetic foot wounds) increases with the increase in the number of diabet sufferers. The design of this study used a descriptive design that aims to describe the filling of capillary blood vessels in patients with diabetic foot ulcer based on the ankle brachial index value. Almost all diabetic foor ulcer patients in the internal room of RSUD Dr. Haryoto Lumajang has trouble filling capillary blood vessels, ranging from mild to severe. And there is only a small percentage of respondents who are not disturbed Setting diet and physical exercise to control blood sugar levels DM patients is very important, considering the impairment of capillary blood vessels often occur in patients with DM Keywords: filling the capiler blood vessel, diabetic foot ulcer

\section{PENDAHULUAN}

Diabetes melittus ( DM ) adalah suatu kumpulan gejala yang ditandai oleh adanya kadar glukosa darah yang tinggi ( hiperglikemia ) yang disebabkan oleh kekurangan hormon pengatur kadar 
glukosa darah ( insulin ), baik secara mutlak yaitu memangkadarnya berkurang atau dapat juga jumlah insulinnya sendiri mencukupi, tetapi kerja insulin yang kurang baik dalam mengatur kadar glukosa darah agar menjadi selalu normal seperti pada orang normal yang tidak menyandang diabetes melitus.

Diabetes Mellitus ( DM ) yang dikenal juga dengan kencing manis atau kencing gula menjadi penyakit yang divonis 'tidak bisa sembuh'. Dalam daftar rengking pembunuh manusia, DM menduduki peringkat keempat. Pada Kongres Federasi Diabetes Internasional di Paris tahun 2003 terungkap bahwa sekitar 194 juta orang di dunia mengidap penyakit ini. Badan Kesehatan Dunia (WHO) memperkirakan pada tahun 2025 jumlah penderitannya akan melonjak sampai 333 juta orang. Di Indonesia predikat diabetes mengenai lebih dari 2,5 juta orang dan diperkirakan terus bertambah.

Terjadinya DM karena kelenjar pancreas tidak lagi memproduksi insulin atau produksinya sangat sedikit sehingga tidak mampu mencukupi kebutuhan tubuh akan hormon insulin. Inilah babak awal kerusakan seluruh organ tubuh.

Secara umum, asupan gula dalam darah disimpan dalam hati. Di sini diolah menjadi glikogen. Jika tubuh memerlukan, hati akan mengeluarkan dan mengolah kembali menjadi glukosa. Bagi orang normal, sebanyak apa pun konsumsi gula tidak mengganggu organ tubuh. Namun, tidak demikian bagi diabetes.

Menurut The National Institute of Diabetes and Digestive and Kidney Disease, diperkirakan 16 juta orang Amerika Serikat diketahui menderita diabetes, dan jutaan diantaranya beresiko untuk menderita diabetes. Dari keseluruhan penderita diabetes, $15 \%$ menderita ulkus di kaki, dan $12-14 \%$ dari yang menderita ulkus di kaki memerlukan amputasi.

\section{METODE}

Desain penelitian menggunakan desain deskriptif yaitu suatu metode penelitian yang dilakukan dengan tujuan utama membuat gambaran atau deskripsi tentang suatu keadaan secara objektif (Soekidjo Notoatmodjo, 2002). Desain deskriptif dalam penelitian ini bertujuan untuk menguraikan tentang pengisian pembuluh darah kapiler pada pasien diabetic foot ulcer berdasarkan nilai ankle brachial index di RSD Dr. Haryoto Lumajang tahun 2014.

\section{HASIL}

Tabel 1 klasifikasi usia pasien diabetic foor ulcer di ruang interna RSUD Dr. Haryoto Lumajang

\begin{tabular}{cccc}
\hline No & Usia & $\sum$ & $\%$ \\
\hline 1 & $41-50$ & 7 & 23.3 \\
2 & $51-60$ & 21 & 70 \\
3 & $61-70$ & 1 & 3.3 \\
4 & $71-80$ & 1 & 3.3 \\
\hline & Jumlah & 30 & 100 \\
\hline
\end{tabular}

Dari tabel 1 sebagian besar usia pasien diabetic foor ulcer di ruang interna RSUD Dr. Haryoto Lumajang adalah 51 60 tahun, yaitu: 21 orang $(70 \%)$

Table 2 Distribusi frekuensi pasien diabetic foor ulcer di ruang interna RSUD Dr. Haryoto Lumajang berdasarkan jenis kelamin

\begin{tabular}{llcc}
\hline No & \multicolumn{1}{c}{ J/K } & $\sum$ & $\begin{array}{c}\text { Prosentase } \\
(\%)\end{array}$ \\
\hline 1 & Laki & 13 & 43.3 \\
2 & Perempuan & 17 & 56.6 \\
\hline & Jumlah & 30 & 100 \\
\hline
\end{tabular}

Dari table 2 sebagian besar jenis kelamin pasien diabetic foor ulcer di ruang interna RSUD Dr. Haryoto Lumajang adalah perempuan, yaitu: 17 orang (56.6 $\%)$.

Table 3 Distribusi frekuensi pasien diabetic foor ulcer di ruang interna RSUD Dr. 
Haryoto Lumajang berdasarkan tingkat pendidikan

\begin{tabular}{clcc}
\hline No & $\begin{array}{c}\text { Tingkat } \\
\text { Pendidikan }\end{array}$ & $\sum$ & $\begin{array}{c}\text { Prosentase } \\
(\%)\end{array}$ \\
\hline 1 & SD & 4 & 13.3 \\
2 & SMP & 5 & 16.6 \\
3 & SMA & 12 & 40 \\
4 & PT & 9 & 30 \\
\hline & Jumlah & 30 & 100 \\
\hline
\end{tabular}

Dari table 3 hampir sebagian tingkat pendidikan pasien diabetic foor ulcer di ruang interna RSUD Dr. Haryoto Lumajang adalah SMA, yaitu: 12 orang $(40 \%)$

Table 4 Distribusi frekuensi pasien diabetic foor ulcer di ruang interna RSUD Dr. Haryoto Lumajang berdasarkan jenis pekerjaan

\begin{tabular}{clcc}
\hline No & $\begin{array}{c}\text { Jenis } \\
\text { Pekerjaan }\end{array}$ & $\sum$ & $\begin{array}{c}\text { Prosentase } \\
(\%)\end{array}$ \\
\hline 1 & Buruh & 14 & 46.6 \\
2 & Pedagang & 2 & 6.6 \\
3 & PNS & 8 & 26.6 \\
4 & Wiraswasta & 2 & 6.6 \\
5 & Petani & 4 & 13.3 \\
\hline & Jumlah & 30 & 100 \\
\hline
\end{tabular}

Dari table 4 hampir sebagian jenis pekerjaan pasien diabetic foor ulcer di ruang interna RSUD Dr. Haryoto Lumajang adalah buruh, yaitu: 14 orang $(46,6 \%)$

Table 5 Distribusi frekuensi pasien diabetic foor ulcer di ruang interna RSUD Dr. Haryoto Lumajang berdasarkan lamanya menderita DM

\begin{tabular}{lllc}
\hline No & $\begin{array}{c}\text { Lama } \\
\text { Menderita } \\
\text { DM }\end{array}$ & $\sum$ & $\begin{array}{c}\text { Prosentase } \\
(\%)\end{array}$ \\
& \multicolumn{1}{c}{ DM } & \\
\hline 1 & $<5$ Tahun & 12 & 40.0 \\
2 & $5 \quad \leq \leq 10$ & 16 & 53.3 \\
& Tahun & & \\
3 & $>10$ Tahun & 2 & 6.6 \\
\hline
\end{tabular}

\begin{tabular}{cccc}
\hline Jumlah & 30 & 100 \\
\hline Dari table & 5 & hampir & sebagian
\end{tabular}
responden lama menderita DM-nya 5 - $\leq$ 10 Tahun di ruang interna RSUD Dr. Haryoto Lumajang, yaitu: 16 orang (53,3 $\%)$. Table 6 Distribusi frekuensi pasien diabetic foor ulcer di ruang interna RSUD Dr. Haryoto Lumajang berdasarkan klasifikasi pengisian pembuluh darah kapiler.

\begin{tabular}{|c|c|c|c|}
\hline No & Usia & $\sum$ & $\begin{array}{c}\text { Prosentase } \\
(\%)\end{array}$ \\
\hline 1 & Normal & 3 & 10 \\
\hline 2 & $\begin{array}{l}\text { Iskemik } \\
\text { Ringan }\end{array}$ & 10 & 33.3 \\
\hline 3 & $\begin{array}{l}\text { Obstruksi } \\
\text { Vaskuler } \\
\text { Sedang }\end{array}$ & 9 & 30 \\
\hline 4 & $\begin{array}{l}\text { Obstruksi } \\
\text { Vaskuler } \\
\text { Berat }\end{array}$ & 8 & 26.6 \\
\hline & Jumlah & 30 & 10.0 \\
\hline
\end{tabular}

Dari table 6 hampir sebagian klasifikasi pengisian pembuluh darah kapiler pasien diabetic foor ulcer di ruang interna RSUD Dr. Haryoto Lumajang termasuk dalam kategori inskemik ringan, yaitu: 10 orang $(33,3 \%)$.

\section{PEMBAHASAN}

Berdasarkan tabel 6 hanya ada sebagian kecil pasien diabetic foot ulcer yang pengisian pembuluh darah kapilernya normal.

Salah satu kerusakan jangka panjang pada system saraf dan pembuluh darah akibat penyakit diabetes mellitus adalah : saraf tepi dengan rasa kesemutan dan rasa baal sedang pada pembuluh darah akan terjadi sklerosis yakni, bila terjadi pada otak dapat menimbulkan stroke, dan pada jantung bisa terjadi penyakit jantung koroner : serangan jantung, pada kaki bisa terjadi luka, gangren/jaringan mati/busuk (Mary Baradero, 2009)

Hal ini sangat sesuai dengan hasil temuan pada penelitian ini dimana hanya ada tiga responden saja yang nilai ankle 
brachial indexnya normal yaitu 1.0 - 1.2; dari ketiga responden tersebut apabila ditinjau dari aspek usianya memang masih usia dewasa dan lamanya menderita diabetes mellitus masih baru saja yaitu $\leq 2$ tahun, sehingga kemungkinan terjadi kerusakan pembuluh darah kapiler belum ditemukan.

Berdasarkan tabel 6 terdapat sepertiga pasien diabetic foot ulcer yang pengisian pembuluh darah kapilernya mengalami iskemik ringan.

Pengisian pembuluh darah kapiler pada pasien diabetic foot ulcer rata-rata akan mengalami kendala seiring dengan berbagai factor resiko baik yang dapat dirubah atau tidak dapat dirubah yang dimiliki oleh masing-masing pasien tersebut seperti berat badan lebih, kurangnya aktivitas fisik, hipertensi, dislipidemia, diet tak sehat, ras, riwayat keluarga dengan diabetes, umur, riwayat melahirkan bayi dengan Berat Badan (BB) lahir bayi $>4000$ gram atau riwayat pernah menderita DM gestasional (DMG) dan riwayat lahir dengan berat badan rendah (Ahmad Rudianto, 2009).

Pada sepertiga pasien yang pengisian pembuluh darah kapilernya mengalami iskemik ringan bila ditinjau dari usianya rata-rata tergolong usia dewasa, dan hanya ada satu saja responden yang berusia lanjut, selain dari factor usia ternyata factor riwayat lamanya menderita diabetes mellitus juga memberikan kontribusi yang signifikan terhadap pengisian pembuluh darah kapiler pada pasien diabetic foot ulcer, dimana rata-rata responden yang mengalami iskemik ringan riwayat lamanya menderita DM kurang dari 5 tahun.

Berdasarkan table 6 hampir semua pasien diabetic foor ulcer di ruang interna RSUD Dr. Haryoto Lumajang mengalami gangguan pengisian pembuluh darah kapiler, dari mulai yang ringan hingga yang berat. Dan hanya ada 3 responden saja yang tidak mengalami gangguan.

Ada tiga faktor yang berperan dalam kaki diabetik, yaitu neuropati, iskemia, dan sepsis. Biasanya, amputasi harus dilakukan. Hilangnya sensori pada kaki bisa mengakibatkan trauma dan potensial untuk ulkus. Perubahan mikrovaskuler dan makrovaskuler dapat mengakibatkan iskemik jaringan dan sepsis. Neuropati, iskemia, dan sepsis bisa menyebabkan gangren dan amputasi. (Mary Baradero, 2009).

Hal ini menunjukkan bahwa masalah gangguan vaskuler pada pembuluh darah kapiler pasien diabetic foor ulcer hampir dipastikan akan terjadi seiring dengan lamanya menderita diabet, dan kemampuan mengendalikan kadar gula darah, selian dari factor usia, sebab 3 tiga responden tersebut tidak ada yang berusia lanjut, walaupun usia sangat berkontribusi terhadap kompatibilitas pembuluh darah seseorang, namun pengaturan pola makan untuk mengendalikan kadar gula darah seseorang jauh lebih penting

\section{KESIMPULAN}

Hampir keseluruhan pasien diabetic foor ulcer di ruang interna RSUD Dr. Haryoto Lumajang mengalami gangguan pengisian pembuluh darah kapiler, dari mulai yang ringan hingga yang berat. Dan hanya ada sebagian kecil responden saja yang tidak mengalami gangguan.

\section{SARAN}

Pengaturan pola makan dan latihan jasmani untuk mengendalikan kadar gula darah pasien DM sangat penting, mengingat gangguan pengisian pembuluh darah kapiler sering terjadi pada pasien DM.

\section{KEPUSTAKAAN}

Baradero, Marry. 2009. Klien gangguan Endokrin : Seri Asuhan Keperawatan. Jakarta: EGC

Hidayat, A. Aziz Akimul. 2007. Metode Penelitian Keperawatan dan Teknik Analisa. Jakarta : Data Selemba Medika 
Hidayat, A. Aziz Akimul. 2003. Riset Keperawatan dan Teknik Penulisan Ilmiah. Jakarta: Selemba Medika

Kozier B, et al. 1995. Fundamental Of Nursing Conceps. Process and Practice 4 the Edition. Addison Wesley : Publishing Company Inc.

Misnadiarly, A, S. 2006. Permasalahan Kaki Diabetes dan upaya Senang. www.tempo.co.id/medika/arsip/200 3/har-htm-19 k (diakses tanggal 10 Desember 2013).

Morison, Moya. 2003. Manajemen Luka. Jatakarta : EGC

Notoatmojo, Soekidjo.2003. Metodologi Penelitian Kesehatan. Jakarta: Rineke Cipta.

Nursalam. 2011. Konsep dan Penerapan Metodologi Penelitian Ilmu Keperawatan. Jakarta: Selemba Medika.

PERKENI.2011. Konsesus Diabetes Mellitus tipe 2 di Indonesia. www.perkeni.org

PERKENI.2009. Konsesus Diabetes Mellitus tipe 2 di Indonesia. www.perkeni.org

Riyadi, Sujono; Sukarmin. 2008. Asuhan Keperawatan pada pasien dengan gangguan Eksokrin dan Endokrin pada Pankreas. Yogyakarta : Graha Ilmu

Smeltzer, S, C dan B, G. Bare.2003. Buku Ajar Kperawatan. Burner \& Suddarth. Jakarta : EGC.

Tandra H, 2008. Segala Sesuatu yang harus anda ketahui Tentang Diabetes Meliyus : Tanggung jawab lengkap dengan ahlinya. Jakarta. Gramedia Pustaka UtamaTaylor C, et al. 1997. Fundamental Of Nursing. The Art and Science Nursing. Addison Wesley : Publishing Company Inc.

Tjokoprawiro, Askandar dkk.2007. Ilmu Penyakit Dalam. Surabaya : Airlangga University Press.

Tjokonegoro, Arjatmo.2003. Pedoman Diet Diabetes Mellitus. Jakarta : FKUI
Yunir, Em. 2007. Ilmu Penyakit Dalam. Jakarta : FKUI.

Waspadji, Sarwono.2005. Ilmu Penyakit Dalam. Jakarta : FKUI 